\title{
VALIDATION OF FOUR NEW PLANT FOSSIL NAMES FROM TURKEY
}

\author{
ÜNAL AKKEMIK
}

Istanbul University-Cerrahpasa, Faculty of Forestry, Department of Forest Botany, 34473, Bahceköy-Sarıyer, Istanbul, Turkey; e-mail: uakkemik@istanbul.edu.tr.

Akkemik, Ü. (2019): Validation of four new plant fossil names from Turkey. - Fossil Imprint, 75(2): 289-291, Praha. ISSN 2533-4050 (print), ISSN 2533-4069 (on-line).

\begin{abstract}
Fossil-wood descriptions from Turkey have been increasing in recent years. The aim of the present paper is to redefine four new fossil species according to the protologue for new plant fossil names. As result, these four new fossil species are verified: Cupressinoxylon pliocenica Аккемік sp. nov., Cercioxylon zeynepae Аккемік sp. nov., Zelkovoxylon yesimae Аккемік et I.Poole sp. nov. and Pistacioxylon ufukii AкKEMIK et I.Poole sp. nov.
\end{abstract}

Key words: validation, fossil wood, description, new species

Received: July 25, 2019| Accepted: September 12, 2019 | Issued: November 25, 2019

\section{Introduction}

Recently, eight new plant fossil-species from Turkey were published by Akkemik et al. (2018), Akkemik (2019) and Akkemik et al. (2019). These new fossil-species are Pistacioxylon ufukii Ü.АКкемIK et I.PooLE and Zelkovoxylon yesimae Ü.AKKemiK et I.Poole (Akkemik et al. 2018), and Cupressinoxylon pliocenica Ü.АКкЕмIK and Cercioxylon zeynepae Ü.Аккемік (Akkemik 2019), and Mimosoxylon ceratonioides Аккемік, Pterocaryoxylon tuncayi Аккемік, Laurinoxylon thomasii Аккемік, Prunoidoxylon aytugii Аккемік (Akkemik et al. 2019). Due to missing information in the protologue for new plant fossil names, the new fossil species described by Akkemik et al. (2018) and Akkemik (2019) were considered invalid by the administrators of Plant Fossil Names Registry Database. The purpose of the present paper is to provide the missing information to validate these four new plant fossil names.

\section{Systematic palaeobotany}

\section{Genus Cupressinoxylon GöPP., 1850}

Cupressinoxylon pliocenica Аккемік sp. nov. Text-fig. 1a

Holotype. YIP01 (Text-fig. 1a, and pls I-II in Akkemik 2019). It is stored at the Department of Forest Botany, Faculty of Forestry, Istanbul University, Istanbul, Turkey.

Plant Fossil Names Registry Number. PFN000547 (for new species).
Etymology. The epithet pliocenica originates from the geological time, Pliocene, of the sample.

Type locality. Close to Yırak Village of the city of Çerkeş, the province of Çankırı, Turkey.

Type horizon. Örencik Formation (Yörük Member), Pliocene.

$\mathrm{D}$ i a $\mathrm{g} \mathrm{n}$ o s i s. Growth ring border in the wood is distinct, transition from earlywood to latewood gradual. Resin canal absent, axial parenchyma common mostly in latewood zone, tracheids mostly circular, intercellular spaces present. Small tracheidal pitting common in tangential section, tracheidal pitting uniseriate in radial section. Rays uniseriate, ray height 3-15 (1-34) cells. Cross-field pits cupressoid and 1-2 pits per cross-field. End walls of axial parenchyma cells both smooth and nodular (Akkemik 2019).

R e m a r k s . For detailed description and discussion see Akkemik (2019).

\section{Genus Cercioxylon AKкемıк gen. nov.}

Ty p e. Cercioxylon zeynepae Аккемік sp. nov.

Plant Fossil Names Registry Numbers. PFN000565 (for new genus).

E t y m o log y. The epithet Cercioxylon originates from the modern genus Cercis L. Because the fossil wood has very similar features to the wood of Cercis, I prefer to use this name for the new genus.

D i a g n o s i s. Wood semi-ring to ring porous. Vessels are in radial multiples and clusters, common or sometimes diffuse. 


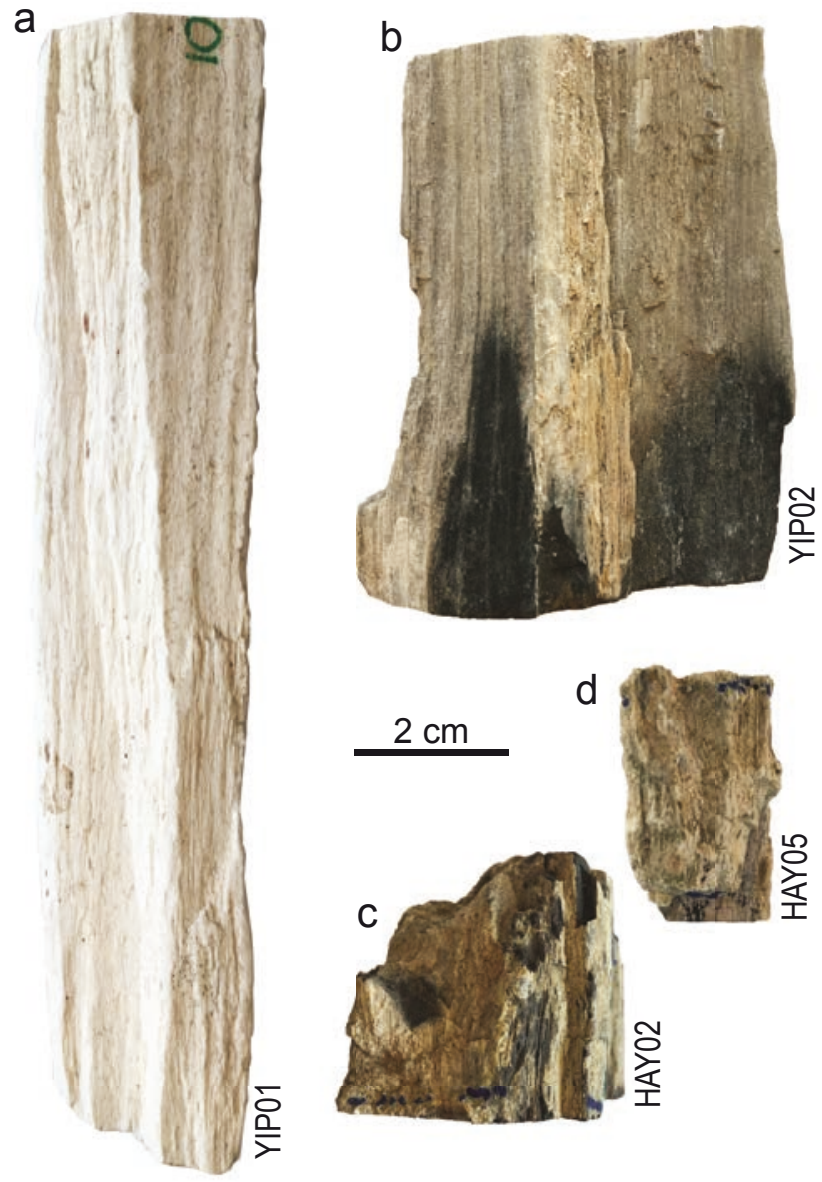

Text-fig. 1. The petrified woods validated as new fossil-species. YIP01 and YIP02 from Akkemik (2019), and HAY02 and HAY05 from Akkemik et al. (2018). a) Cupressinoxylon pliocenica Аккемік sp. nov. No. YIP01 (holotype); b) Cercioxylon zeynepae Аккемік sp. nov. No. YIP02 (holotype); c) Zelkovoxylon yesimae АкКеMIK et I.Poole sp. nov. No. HAY02 (holotype); d) Pistacioxylon ufukii AкKemik et I.Poole sp. nov. No. HAY05 (holotype).

Perforation plates simple. All rays procumbent in general, and body rays procumbent with one to four upright cells. Axial parenchyma paratracheal to vasicentric and in confluent type, banded, and in dendritic to net-like groups with vessels, and axial parenchyma storied, 2-4 cells per parenchyma strands. Ray width up to 5 seriate (2-4 in general), and uniseriate rays 5-15 cells. Vestured ray pits present (Akkemik 2019).

R e m a rks. For discussion to the genus see Akkemik (2019).

\section{Cercioxylon zeynepae АКкемік sp. nov.} Text-fig. $1 \mathrm{~b}$

Holotype. YIP02 (Text-fig. 1b, and pls V-VI in Akkemik 2019). It is stored at the Department of Forest Botany, Faculty of Forestry, Istanbul University, Istanbul, Turkey.

Plant Fossil Names Registry Number. PFN000548 (for new species).
E ty m o log y. The epithet zeynepae originates from the name Zeynep. I have used it to honor my wife, as she has been a most patient partner throughout my hard scientific life.

Type locality. Close to Yiprak Village of the city of Çerkeş, the province of Çankırı, Turkey.

Type horizon. Örencik Formation (Yörük Member), Pliocene.

D i a g n o s i s. Wood semi-ring to ring porous. Vessels in short radial pattern up to 6 cells, and clusters common. Mean tangential and radial diameters of earlywood vessel lumina $84(52-132) \mu \mathrm{m}$ and $82(32-135) \mu \mathrm{m}$, respectively, and their shapes almost circular, they are $30(11-47) \mu \mathrm{m}$ and 32 $(12-48) \mu \mathrm{m}$ in the latewood, respectively. Vessel frequency 40-100 per $\mathrm{mm}^{2}$. Perforation plate simple. Fibers thin- to thick-walled. Axial parenchyma paratracheal to vasicentric and in confluent type, banded, and in dendritic to net-like groups with vessels, axial parenchyma storied, and 2-4 cells per parenchyma strands. Rays 1-5 (2-4) seriate, multiseriate ray height generally 18-27 (max. 56) cells, and uniseriate rays $5-15$ cells. $6-12$ rays per $\mathrm{mm}$. All rays procumbent or body ray cells procumbent with one to four square marginal cells, vestured ray pits common (Akkemik 2019).

Remarks: For more detailed description and discussion see Akkemik (2019).

\section{Genus Zelkovoxylon Greguss, 1969}

\section{Zelkovoxylon yesimae Аккемік et I.Poole sp. nov. Text-fig. 1c}

Holotype. HAY02 (Text-fig. 1c, and pls IV-V in Akkemik et al. 2018). It is stored at the Department of Forest Botany, Faculty of Forestry, Istanbul University, Istanbul, Turkey.

Plant Fossil Names Registry Number: PFN000362 (for new species).

E t y m o log y. The epithet yesimae originates from the name Yeşim. It is used in honor of Yeşim Akkemik, as she has been one of the most patient persons in my very hard scientific life.

Type locality. Near the village of Çayraz in the Haymana Basin (Ankara) at 32 $33^{\prime} 49^{\prime \prime} \mathrm{E}$ and $39^{\circ} 28^{\prime} 46^{\prime \prime} \mathrm{N}$.

Type horizon. Canımana ignimbrite member of the Yenice volcanics, with age of $24.7 \pm 1.9 \mathrm{Ma}$, i.e. latest Oligocene-early Miocene (Atıc1 et al. 2014).

Diagnosis. Wood of the new species is ring porous; earlywood vessels wider and in 2-3 rows; solitary or up to 4 vessels in radial multiples; latewood pores are narrow, generally in clusters and diagonal bands. Rays are heterocellular, body ray cells procumbent with one or two rows of upright cells, and ray width 1-2 seriate. Prismatic crystals common in the axial parenchyma cells (Akkemik et al. 2018).

$\mathrm{R}$ e $\mathrm{m}$ a r k s . For detailed description and discussion see Akkemik et al. (2018). 
Genus Pistacioxylon J.Dupéron, 1973

Pistacioxylon ufukii AKKeMIK et I.Poole sp. nov. Text-fig. 1d

Holotype. HAY05 (Text-fig. 1d, and pls II-III in Akkemik et al. 2018). It is stored at the Department of Forest Botany, Faculty of Forestry, Istanbul University, Istanbul, Turkey.

Plant Fossil Names Registry Number. PFN000361 (for new species).

Etymology. The epithet ufukii originates from the name Ufuk. It is used in honor of Ufuk Akkemik, as he has been one of the most patient persons in my very hard scientific life.

Type locality. Near the village of Çayraz in the

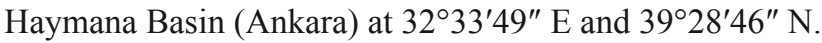

Type horizon. Canımana Ignimbrite Member of the Yenice volcanics, with age of $24.7 \pm 1.9 \mathrm{Ma}$, i.e. latest Oligocene-early Miocene (Atıc1 et al. 2014).

Diagnosis. Growth ring boundaries distinct and wood ring-porous. Earlywood vessels 1(-2) seriate and transition from earlywood to latewood is abrupt. Tyloses common in wider vessels. Latewood vessels occur in narrow dendritic pattern and clusters. Perforation plate simple. Rays 1-5 seriate and 6-12 per mm. Radial canals are common in rays and their number 1-3 per ray. Ray width generally 1-2 seriate (to 5 seriate around the radial canals). Ray height 5-20 cells. Rays heterocellular and body ray cells procumbent with mostly 1-4 rows of upright and/or square marginal cells (Akkemik et al. 2018).

R e m a r k s . For detailed description and discussion see Akkemik et al. (2018).

\section{Acknowledgements}

I would like to thank Dr. Jiří Kvaček and the reviewers for their valuable contributions for the validation of the new descriptions and evaluation of the paper.

\section{References}

Akkemik, Ü., Atıcı, G., Poole, I., Çobankaya, M. (2018): Three new silicified woods from a newly discovered earliest Miocene forest site in the Haymana Basin (Ankara, Turkey). - Review of Palaeobotany and Palynology, 254: 49-64. https://doi.org/10.1016/j.revpalbo.2018.04.012

Akkemik, Ü. (2019): New fossil wood descriptions from Pliocene of central Anatolia and presence of Taxodioxylon in Turkey from Oligocene to Pliocene. - Turkish Journal of Earth Science, 28: 398-409. https://doi.org/10.3906/yer-1805-24

Akkemik, Ü., Akkılıç, H., Güngör, Y. (2019): Fossil wood from the Neogene of the Kilyos coastal area in Istanbul, Turkey. - Palaeontographica, Abt. B, 299(1-6): 133-185. https://doi.org/10.1127/palb/2019/0065

Atıcı, G., Dönmez, M., Çobankaya, M., Sevin, M., Gündoğdu, E., Esirtgen, E., Şimşek, E. (2014): 1:100.000 Scale Geological Map of Ankara J29. - MS, General Directorate of Mineral Research and Exploration (MTA), Ankara, Turkey. (unpublished)

Dupéron, J. (1973): Oleoxylon aginnense n. gen. n. sp., Pistacioxylon muticoides n. gen. n. sp., bois fossiles tertiaires de la région de Grateloup (Lot-et-Garonne). Journal Bulletin de la Société Botanique de France, 120(7-8): 311-330. https://doi.org/10.1080/00378941.1973.10839173

Göppert, H. R. (1850): Monographie der Fossilen Coniferen. - Natuurkundige Verhandelingen van de Hollandsche Maatschappij der Wetenschappen te Haarlem, $2^{\text {nd }}$ Ser., 6: 1-286 + 1-73 + 58 pls.

Greguss, P. (1969): Tertiary angiosperm woods in Hungary. - Akadémiai Kiadó, Budapest, 151 pp. 